Biannual Research Journal Grassroots

Vol.55, No.II, 2021: 1-21

Grassroots

\title{
PAKISTAN'S ALLIANCE WITH CHINA: AN INSIGHT FROM BALANCE OF THREAT THEORY
}

\author{
Safdar Hussain, PhD \\ Assistant Professor, Department of Political Science, \\ The Islamia University of Bahawalpur, Pakistan. \\ Email:safdar.hussain@iub.edu.pk
}

\begin{abstract}
International Alliances has been fundamental in Pakistan's international interaction. Yet, this significant event has persisted understudied. Pakistan's need for external alliances is promoted by the increased security threat and difficulties in relationship mainly with India. The political survival and difficulty in maintaining political independence made it necessary for the Islamabad security elites to seek alliances with major powers that enable them to deal with India and to a lesser extent Afghanistan. Using Balance of Threat Theory for explaining international alliances as a theoretical basis, this research examines a very fundamental question why does Islamabad need an external alliance? And how Pakistan seeks alliance with China. The relationship between external threats and Pakistan's alliance making behaviour is studied using mainly primary and secondary literature. The primary resources are secured through qualitative interview conducted between 2014 and 2016 with current and former Pakistani security elites as part of PhD project.
\end{abstract}

Keywords: Alliances, Balance of Threat Theory, Balance of Power, Security, Pakistan, Afghanistan, and India.

\section{BACKGROUND OF THE RESEARCH}

In this section, we will discuss a brief history of the study to emphasis the context and significance of the research. Furthermore, we hope to provide a concise overview of the historical developments in the literature that led to the current topic of research. The alliance between Pakistan and China is one of the closest in the world; it is also one of the least understood in the world. One of the most secretive relationships in world, it has not received much attention. Given the fact that seeking security through external alliance has been the cornerstone of Islamabad's foreign policy, it would be expected that there would a lot of literature on Pakistan-China alliance, but this 
extraordinary phenomenon has not received much attention, and even the available literature is irregular and fragmented.

One has to amalgamate the thread and join sparsely available literature to get sense of Pakistan's alliance making with China. Nevertheless, there are several studies which discuss various aspects of Pakistan's relations with China. There are findings that discuss the origins and rationale of Pakistan-China relations (Anwar Syed, 1974), (Latif Sherwani), (Yaacov Vertzberger), (Rasul Bakhsh Rais), (Birendra Nath Goswami, 1971), (Swaran Singh 2007), (Muhammad Ijaz Butt, 2007), and there are chapters within the books which discuss the origin and further development of Pakistan-China relations (S.M.Burke 1974), (Mujtaba Rizvi 1971), (M. A. Chaudhri, 1970), (Sanghat Sing, 1977), (K.B. Sayeed, 1981), (Gurnam Singh, 1984). Former Pakistani diplomats have made their own contribution, citing a number of personal sources that have been a major source of Pakistan's relationship with China (Shahid Amin 2002), (Abdul Sattar 2005).

There is also discussion about the mutual issues like Uighur separatism and its impact on Sino-Pakistan relations. (Ahmad Faruqi 2001), (Ziad Haider 2005), (Shahzad Akhtar 2009), (Jayshree Bajoria 2008), (Bhattacharji 2009), (Pantucci, 2012). While others believe that Pakistani security elites have overestimated the alliance, the actual content and productivity of the alliance is not as significant as Islamabad has predicted (Lisa Curtis, 2012), (Michael Beckley 2012), (Kabraji, 2012), (Andrew Small 2010).

Many foreign authors have been analyzing the impact of international development on Pakistan China relations mainly in the post-cold war era (John W. Garver, 1996), (John W. Garver, 2005), (John Garver, 2004), (John Garver), (John W. Garver, 2002), (Devin Hagerty, 2002), (Willem van Kemenade, 2008). Some have highlighted Chinese role in Indo-Pakistan bilateral disputes (Ghulam Ali, 2003), (Ahmad Faruqi 2001), (Ahmad Faruqi 2001), (Akhtar 2009). While other have fiven importnance to the emerging chalnnge which have the potential to derail Sino-Pakistan relations (Ziad Haider, 2005), (Ziad Haider 2009). In recent studies, this relationship has been treated holistically covering some important aspects such as military cooperation and emerging trends such as economic relations between the two countries (Andrew Small 2016), (Filipino Boni 2020). Nevertheless, earlier studies have ignored the use of theories of 
international politics to study Pakistan's alliance-making behaviour. In this regard, this study employs BoT to investigate the phenomena under consideration. Therefore, current study has been designed to fulfill this lacuna.

The remaining article explains, first of all, Balance of Threat Theory, followed by a discussion about the Pakistani security establishment threat perception and finally, a link between the BoT and the establishment and further development of Pakistan's China alliance.

\section{BALANCE OF THREAT (BoT) THEORY EXPLAINED}

This study agrees with the traditional Balance of Power (BoP) theories, and in particular Stephen Walt's Balance of Threat theory (BoT) that states seek alliances to balance external threats. In sharp contrast to traditional balance of power theory, Walt's theory maintains that states react to an imbalance of threat rather than imbalance of power alone. The dominant driver in Pakistan's foreign policy has been to correct any imbalances of threat which exist between Islamabad and its neighbours, mainly India, but also Afghanistan mildly. An attempt is made to investigate threats to Pakistan's security and its strategies to counterbalance threats using Walt's BoT theory framework. BoT aptly explicates determinants that trigger Pakistan's drive for alliance formation.

Traditional approaches in International Relations maintain that states operate as unitary actors in an international system, which is generally characterized by anarchy. It lacks a superior world government, which could protect states when threatened by other state or a group of states. In the absence of such a mechanism, states devise strategies of self-help to enhance military capability to prevent other states conquering them. States do this either by building up internal capability, or they import power of other states called external balancing. This logic has mainly given rise to the plethora of realist theories.

The balancing strategies are manifested in the framework of Balance of Power theories, chiefly found in Waltz's Theory of International Politics (1979) and Walt's Origin of Alliance (1987). These scholars have some common and some divergent points with regards to their respective theories. As an illustration, both agree that states seek security through alliances to maintain their independent 
status without being dominated by other states. Contrarily, there is a difference of opinion concerning how they approach alliance formation. On the alliance formation, Waltz articulates those states will consider 'distribution of capabilities' most important factor. On the other hand, Walt argues that the 'distribution of power' is an extremely important factor, and the level of threat is also enhanced by geographic proximity, offensive capabilities, and perceived intentions. BoP and BoT theories, however, are intrinsically different as the former aims to balance the imbalance of power while the BoT attempts to balance the imbalance of threat (Walt, 1987), (Walt, 1985), (Kenneth N. Waltz, 1979), (Gulick Edward, 1967), (Hans Morgenthau, 1948).

Furthermore, Waltz maintains that states pursue balancing strategies primarily for two reasons. Firstly, they try aligning against the strongest states to prevent the overall control of the system by any single state or a coalition of states, in order to maintain an equilibrium; and secondly, by joining a weaker or more vulnerable side, nationstates maximize their relative influence (Kenneth Waltz, 1979:127). For Waltz, balancing, which is a self-protective means of survival, can be pursued both internally and externally, although internal balancing is more secure and reliable (Kenneth N. Waltz, 1979:166). During the cold war, the superpowers sought alliances, however they also accumulated a stockpile of nuclear weapons to balance internally.

While Walt acknowledges Waltz's contributions/explanations, but he attempts to address the inadequacies in the latter's postulation through his own theory. For instance, Walt acknowledges Waltz's systematic variable of alliance formation (where the distribution of capabilities is a crucial factor) but enlarges the concept of seeking by including systematic, material, and cognitive factors into the perception of threat and formation of alliances. Thus, Walt, like Waltz, uses alliances as dependent variables, but unlike Waltz he elucidates behaviour rather than outcome. Finally, Walt maintains that balancing is far more common than 'bandwagoning' as it is more secure: "balancing is allying with other against the prevailing threat, bandwagon refers to alignment with the source of danger" (Walt, 1987:17), (Walt, 1985).

Pakistan, which is a mid-power state, is mainly concerned about regional imbalance of threat, and seeks both internal and external 
balancing. It is also pertinent to point out that Pakistan has also utilized external balancing to achieve internal balancing over the course of its eventful existence. It is the most threatening states in the region which present a threat to its survival, and so Walt's BoT is an appropriate model for studying Pakistani alliance making behaviour. Though power is an important factor, Indian intentions, geography, and offensive power make Pakistan vulnerable to the Indian threat. Indian intent and capability in terms of its imposing geography, superior conventional arsenal and a relatively bigger economy coupled with Pakistan's vulnerabilities in the form of disadvantaged geography, inferiority in terms of conventional military capability and an ailing economy curtail Pakistan's options.

\section{RESEARCH METHODOLOGY}

To that end, this study makes use of both primary and secondary sources. The primary sources are drawn from interviews with former and serving Pakistani and Chinese elites conducted as part of a $\mathrm{PhD}$ project between 2014 and 2016. Former ambassadors, foreign secretaries, foreign ministers, academics, and media representatives are among those who have interviewed to obtain first-hand information about the phenomenon.

Elements Upsetting Islamabad's Threat Level: Nation-states perform numerous functions, but defence and national security are the most important. States just cannot ignore them, and Pakistan is no exception to this, its security has been challenged since independence in 1947. Carved out of British India in 1947, it has been on a continuous search for security. Pakistan must deal with both external and internal threats. Externally, it receives a blend of tacit and real threats from all its neighbours, India, and Afghanistan. Though the catalogue of issues and gravity of threats vary between the neighbours, it considers India to be a permanent and dangerous adversary. They conflict each other on a wide range of issues, from ideological to territorial to distribution of water resources. Perhaps it would not be exaggeration to say that both sides have committed to perpetual strategic and political competition. Stephen Cohen has persuasively argued that the rivalry between Pakistan and India has the potential to become the longest rivalry in the modern history of the international relations (Stephen P. Cohen, 2013). This unrivalled rivalry between these South Asian neighbours has continued to be a cause of concern 
for the international community especially post overt nuclearization. Similarly, Pakistan intermittently receives both implied and direct threats from Afghanistan. The conflicting views about the demarcation of the international boundary (commonly known as the Durand Line) are the enduring issue in their bilateral relationship.

Indian Aggregate Power: The leading scholars of international politics generally define power in measurable terms. For instance, Waltz believes that the fundamentals of power are "size of population and territory, resource endowment, economic capability, military strength, political stability and competence" (Kenneth N. Waltz, 1979:131). Morgenthau provides a long list of elements of power including geography, natural resources (for example, oil, food and so on), strength of industry, how well the military is prepared (including levels of technological development, leadership, and the quality and quantity of armed forces), the distribution of population and demographic trends, national character and morale and the quality of diplomacy and government (Hans Morgenthau, 1948:124-164). John Mearsheimer sees power in military capabilities (Mearsheimer 2001:56-61). Finally, Walt maintains that "the greater a state's total resources (e.g., population, industrial and military capability, and technical prowess), the greater a potential threat it can pose to others" (Walt, 1987:22). Military strength and economic capability are the most common and dominant factors in making states powerful or weak. States endowed with great military capability, and advanced weaponry/technology can dominate other states. Similarly, a strong economy can build up a powerful military state.

In 2019, India-Pakistan relations took a dramatic turn for the worse due to terrorist attacks on Indian forces in occupied Kashmir as the two countries bombed each other, captured, and then released soldiers and claimed victory to muster local support. Competition between the two countries is often powered by the serious ideological and geopolitical differences. Pakistan is an Islamic country secured in the name of Islam, while India claims to be a secular state. Indian Muslims fought against the British and Hindus to claim Pakistan. In addition, India claims regional hegemony and does not allow smaller states to seek security outside the region. Rather, it wants them to rely on India for security and economic recovery. Pakistan abhors the 
Indian model of South Asia and believes it is based on domination and intimidation.

The traditional imbalance which exists between India and other South Asian states needs no elaboration. There exists a huge disparity in power, size, resources and population between India and other states in the region. India is comparatively more advanced and industrially developed, whereas Pakistan is weak and dependent on foreign aid. The World Bank reports that Indian GDP for 2014 was \$2 trillion, while Pakistan's has only $\$ 243$ billion, roughly 12 percent of India's (World Bank, 2015). Generally, the gap that exists between the two states is widening and to a certain extent natural which is unlikely to be balanced in numerical terms.

The Partition itself gave India an edge over Pakistan; the division of assets favoured India with a 2:1 ratio, and areas settled by the British Raj, industrial installations, military cantonments, and developed infrastructure were to be found in India, not Pakistan. Indian's withholding of Pakistan's shares complicated military and defence requirements (Sherwani, 1967). Although Pakistan is much better in military capabilities when compared with its economy, in comparison with India, Indian military capabilities are far superior. Indian army is equipped well both qualitatively and quantitatively (see Table-1).

\begin{tabular}{|c|c|c|c|}
\hline $\begin{array}{l}\text { Sr. } \\
\text { No }\end{array}$ & Items & India & Pakistan \\
\hline 1 & $\begin{array}{l}\text { Military } \\
\text { budget }\end{array}$ & $\begin{array}{l}(\$ 58 \mathrm{bn}) \text {, or } 2.1 \text { percent } \\
\text { of its gross domestic } \\
\text { product }(\mathrm{GDP})\end{array}$ & $\begin{array}{l}(\$ 11 \mathrm{bn}) \text {, about } 3.6 \text { percent of } \\
\text { its GDP }\end{array}$ \\
\hline 2 & $\begin{array}{l}\text { Missiles } \\
\text { and } \\
\text { nuclear } \\
\text { weapons }\end{array}$ & $\begin{array}{l}\text { nine types of } \\
\text { operational missiles } \\
140 \text { to } 150 \text { nuclear } \\
\text { warheads, }\end{array}$ & $\begin{array}{l}\text { tactical nuclear weapon } \\
\text { capability, wherein smaller } \\
\text { nuclear warheads are attached } \\
\text { to short-range missiles (50- } \\
100 \mathrm{~km}) \text { compared with India's } \\
130-140 \text { warheads, }\end{array}$ \\
\hline 3 & Army & $\begin{array}{l}1.2 \text { million-strong } \\
\text { army, supported by } \\
\text { more than } 3,565 \text { battle } \\
\text { tanks }\end{array}$ & $\begin{array}{l}560,000 \text { troops backed by } \\
2,496 \text { tanks }\end{array}$ \\
\hline 4 & Air Force & $\begin{array}{lr}\text { With } & 127,200 \\
\text { personnel and } 814 \\
\text { combat aircraft, India's }\end{array}$ & $\begin{array}{l}\text { Pakistan has } 425 \text { combat } \\
\text { aircraft, including the } \\
\text { Chinese-origin F-7PG and }\end{array}$ \\
\hline
\end{tabular}


Biannual Research Journal Grassroots Vol.55, No.II: 1-21

\begin{tabular}{|c|c|c|c|}
\hline & & $\begin{array}{l}\text { air force is } \\
\text { substantially larger but } \\
\text { there are concerns } \\
\text { about its fighter jet } \\
\text { fleet. } \\
\text { India's defence plans } \\
\text { require } 42 \text { squadrons } \\
\text { of jets, about } 750 \\
\text { aircraft, to defend } \\
\text { against a two-pronged } \\
\text { attack from China and } \\
\text { Pakistan }\end{array}$ & $\begin{array}{lll}\text { American } & \text { F-16 } & \text { Fighting } \\
\text { Falcon jets } & & \end{array}$ \\
\hline 5 & Navy & $\begin{array}{l}\text { India's navy consists } \\
\text { of one aircraft carrier, } \\
16 \text { submarines, } 14 \\
\text { destroyers, } 13 \text { frigates, } \\
106 \text { patrol and coastal } \\
\text { combatant vessels, and } \\
75 \text { combat-capable } \\
\text { aircraft. } \\
\text { It has } 67,700 \\
\text { personnel, including } \\
\text { marines and naval } \\
\text { aviation staff. }\end{array}$ & $\begin{array}{l}\text { Pakistan, which has a } \\
\text { significantly smaller coastline, } \\
\text { has } 9 \text { frigates, } 8 \text { submarines, } \\
17 \text { patrol and coastal vessels, } \\
\text { and } 8 \text { combat-capable aircraft. }\end{array}$ \\
\hline
\end{tabular}

Table-1: India vs Pakistan: Military Strength and Arsenal. (Aljazeera, India vs Pakistan: Military Strength and Arsenal, 26 Feb 2019 source: https://www.aljazeera. com/news/2019/2/26/india-vs-pakistan-military-strength-and-arsenal retrieved on 24.5.2021)

Despite Pakistan's outlay on defence being more than India's in terms of GDP ratio, in absolute terms Indian spending outranks that of Pakistan: The Indian defence budget has crossed the $\$ 70$ billion mark, whereas Pakistan's is a paltry $\$ 10$ billion (Amin Ahmad, 2020). The disparity between the armies of India and Pakistan bolsters Pakistan's fears of Indian threat. Like India, Pakistan possesses nuclear weapons (see Figure-1), at a level which expert believe to be growing quickly (George D. Koblentz, 2014), a notion disputed by Pakistani analysts, (Mansoor Ahmed 2015), numerically, in terms of the size of the military, Pakistan is not going to match India (Shamshad Ahmad Khan Personal Communication, June 20, 2015). It has not happened before, 
and it is unlikely to happen in the future; in fact, the BBC defence correspondent Jonathan Marcus suggests that "[i]n straight numerical terms of population, economic might, military manpower and equipment it is almost meaningless to speak about an India-Pakistan balance" (Quoted in Muhammad Aslam Khan Niazi, 2011).

2020 Estimated Global Nuclear Warhead Inventories

The world's nuclear-armed states possess a combined total of nearly 13,500 nuclear warheads; more than $90 \%$ belong to Russia and the United States. Approximately 9,500 warheads are in military service, with the rest awaiting dismantlement.

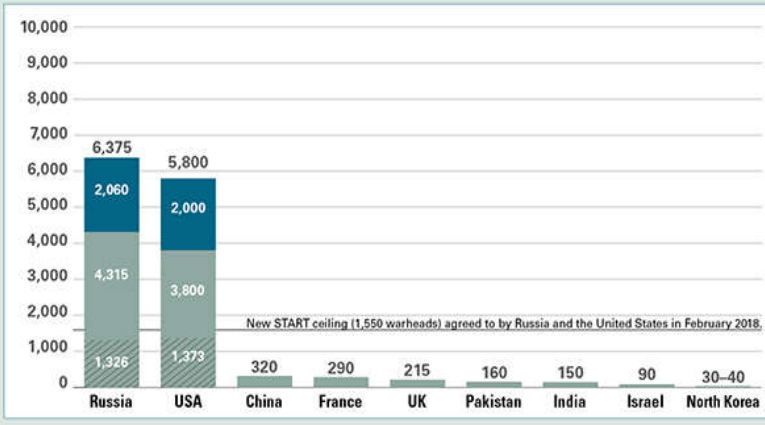

Source: Hans M. Kristensen, Shannon N. Kile, Stockholm International Peace Research Institute, and the U.S. Department of State. Updated: August 2020

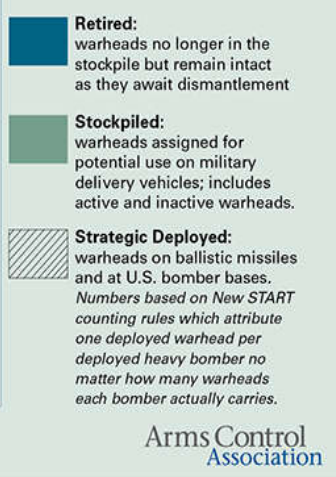

Figure-1 Source: https://www.armscontrol.org/factsheets/Nuclearweaponswhohaswhat

To be brief, the power asymmetry which exists between India and Pakistan has enhanced Pakistan's security worries, and it is one of the main reasons for seeking balancing strategies to keep parity with India in conventional and non-conventional security challenges, and to obtain a range of non-military benefits like enhanced trade and economic support. The Indo-Pak rivalry is a fundamental feature in the South Asian region.

\section{GEOGRAPHIC PROXIMITY}

Geography plays an important part in terms of shaping a nation's security considerations. Despite developments in military warfare and reconnaissance, air-power and military communication systems, and precision and accuracy in striking enemy targets (generally known as revolution in military affairs or RMA), it is a central factor in shaping nation's security challenges. Both Nicholas Spykman and Martin Sicker maintain that geography is the most fundamental factor in shaping any nation's foreign policy (Martin Sicker, 2010). Nonetheless, the political and strategic meaning of geography is not 
static, it is subject to change as the ways and means of waging war undergo a transformation.

Geographical proximity is important as threats close by are more viable than distant threats. It necessitates that if a relationship cannot be perfect between neighbouring states, it should at least be cordial. While states can enjoy the luxury of choosing their friends, seldom are they able to choose their neighbours. In a region fraught with tension due to the policies of regional states who aspire to positions of power, the survival of neighbouring, weaker, states are endangered and proactive policies are required to guard the frontiers of the state and national security.

India, owing to its size and resources, seeks a major role in South Asian affairs. Pakistan finds it hard to maintain its status as a sovereign and independent nation, as it comes up against Indian attempts to dominate the region. According to Walt, "[b]ecause the ability to protect power declines with distance, states that are nearby pose a greater threat than those that are far away" (Walt, 1987:23). Islamabad's policies would have been entirely different, and it could have been more secure, if it was located further away from India. Brigadier Naeem Salik, a retired Pakistani army officer, maintains that Pakistan, which has one of the largest populations in the world and good territory size, would have played an entirely different and much more active role in world affairs had it been located in any region other than South Asia. Pakistan's refusal to bandwagon in the South Asian context has triggered an adversarial relationship with India. If India were situated far away from Pakistan, the latter's perception of threat would have been entirely different as it would not have to face Indian attempts to dominate the region. 


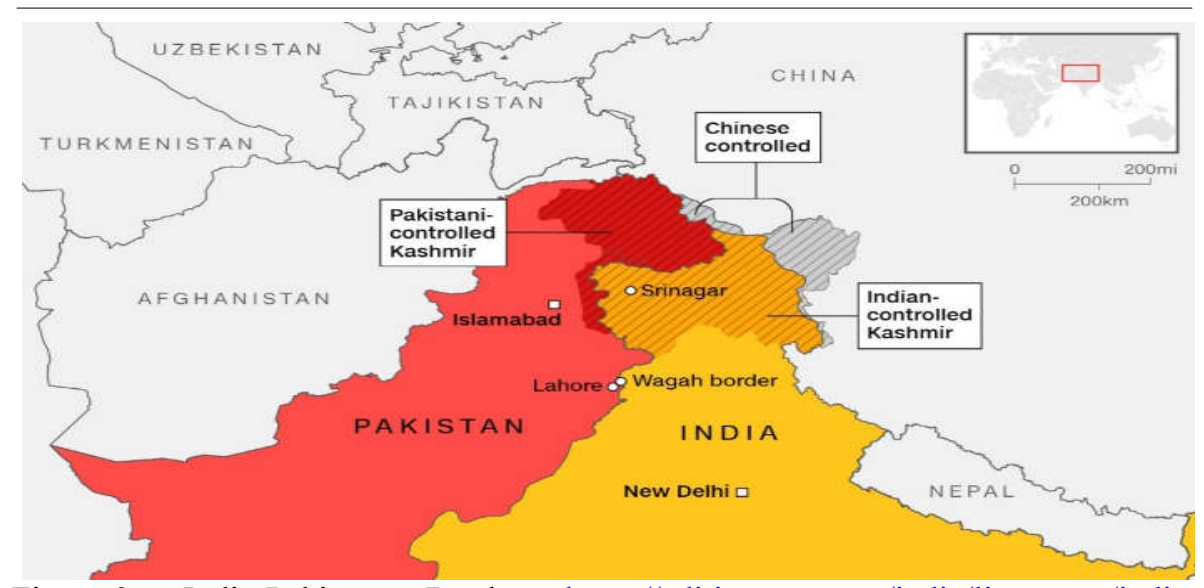

Figure-2: India-Pakistan Border https://edition.cnn.com/india/live-news/indiapakistan-kashmir-dle-intl/index.html

Furthermore, Pakistan's security problems are intensified because Islamabad must address vulnerabilities arising from its geographical layout. Arguably, if the Pakistani strategic planners had been given an opportunity to decide country's location, they would have opted to be situated away from India, and if not, they would have liked to have strategic depth in their territory as territory/landscape of Pakistan provides little opportunity for strategic defence (Tanveer Ahmad Khan, Personal Communication, January 9, 2016). While India's vast geography provides it with ample depth from a military point of view as Indian territory stretches all the way down to the Indian oceans, and expands eastward up to Myanmar (see Fig 2); in contrast, Pakistan's landscape is tapered in width with a rough length of $500 \mathrm{~km}$. For Pakistan, it a serious handicap in terms of operational strategy and poses a significant disadvantage against an attacking Indian army which can easily cut across the strip and halt communications systems that exist between the south and north parts of the country (Hasan Askari Rizvi, 1993:1-17).

Lack of strategic depth hampers Pakistan's ability to regroup in depth and attempt to retake lost territory in case it suffered a setback in the initial stages of a future war. The lack of territorial strategic depth has forced Pakistani security establishment to develop erroneous concept of interfering in Afghanistan to establish a friendly regime. Also, the strategic shortfall in the territory has affected Pakistan's nuclear policy of no first use of nuclear weapons. Bhumitra Chakma 
maintains that India insists that both Pakistan-India should sign no first use of nuclear weapons, Pakistan declines to sign partly due to lack of depth-ness in the territory (Bhumitra Chakma, 2009). Additionally, Pakistan's core defence lines in Sindh and Punjab are areas of strategic vulnerability as Pakistan lacks the military technology to cope with such a landscape during the wars with India. All trade centres, major cities and strategic roads and rail connections are situated a few kilometres away, parallel to the Indian territories. Pakistan was bordered by major military cantonments. Thus, as Pakistan permanent representative to the UN Maleeha Lodhi maintains, "The tyranny of geography has imposed heavy burdens on Pakistan. It has influenced its security thinking and calculus as well as posed enduring security dilemmas" (Maleeha Lodhi, 2014).

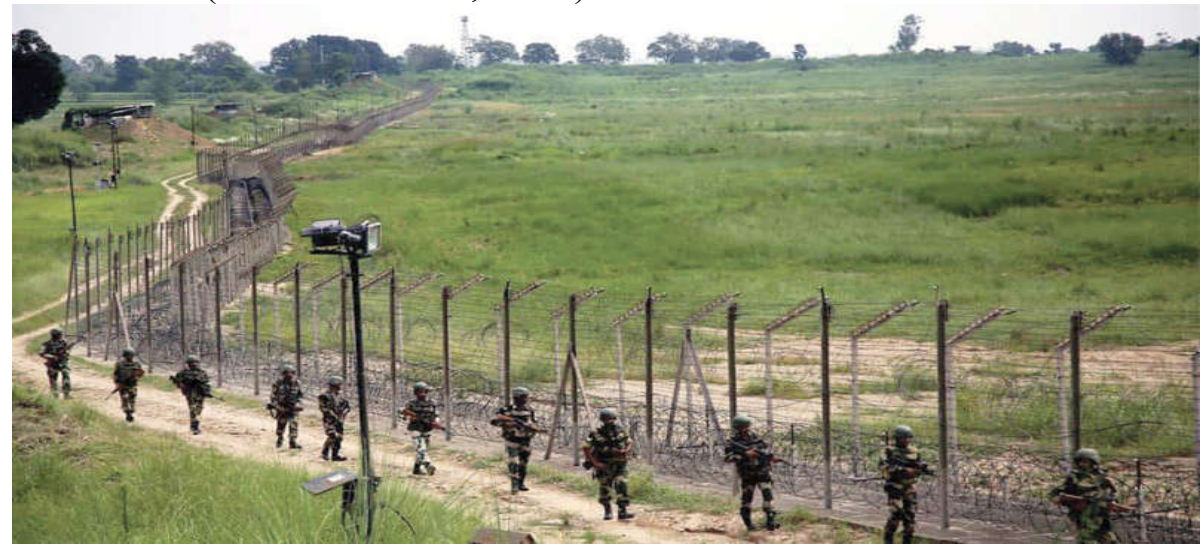

Figure-3: India-Pakistan border is one of the heavily guarded borders globally.

Indian geography gives it control over Pakistan's water resources, another disadvantage/threat that Pakistan faces due to India's physical location. Furthermore, India has been determined to violate the World Bank-mediated Indus Waters Treaty of 1960. As India controls the land in the Kashmir region it has been controlling Pakistan's water in violation of the treaty by constructing dams on the Chenab and Jhelum rivers to aggravate the economic security of waterstarved Pakistan. Pakistan's former Indus Waters Commissioner Jamaat Ali Shah stated "We are already a water-stressed country" and that Indian attempts to construct dams are "aggravating the stresses" (Amol Sharma and Tom Wright, 2010). 


\section{OFFENSIVE POWER}

Walt maintains that "All else being equal, states with large offensive capabilities are more likely to provoke an alliance than are those that are incapable of attacking because of geography, military posture, or something else" (Walt, 1987:24). Walt further argues 'Offensive capability is associated primarily with aggregate power, but it is actually quite different: an aggregate power can be converted into an offensive power through building up an enormous mobile military capability (Walt, 1987:24). While aggregate power can partly be due to natural differences (for example size, population, or natural resources) offensive capability arguably is a measured attempt to make a threatening stance towards other states. Pakistan official's do not obscure their feeling calling India an offensive power bent to undo Pakistan (Munir Akram, 2016). A huge majority (about 70 per cent) of Indian armed forces are positioned to face Pakistan and not China, which presents a constant threat and considered by Islamabad an act of belligerence (Maleeha Lodhi, 2014), Munir Akram, 2015).

Historically, India has resorted to the stratagem of mobilizing its troops on the border in order to intimidate Pakistan. In 1950-51, India deployed armed forces alongside Pakistan's border when there was little military cause for doing so; in 1987-88, India carried out the largest military exercises, code-named 'Brass Tacks', near the Pakistani border for four months, triggering a serious crisis as Pakistan retaliated with its own total mobilization. South Asia crisis expert P.R. Chari stresses that the Indian mobilization set the countries on a collision course, as full-fledged war was very distinct possibility (Chari 2003). Seymour Hersh even suggested Pakistan had put the nuclear option on the table in order to defuse the crisis (Seymour Hersh, 1993). Not long after that incident, India again assembled troops on Pakistan border in the wake of uprising in Indian-held Kashmir in 1990. Yet again, Pakistan countered with deployment of its troops on the Indian border with option of nuclear exchanges (Stephen Cohen 2000). These contingencies not only created unsolicited worries in Islamabad but put extra strain on economy to mobilize troops.

India's aggressive posture also showed in its drive to acquire weapons worth billions of dollars, thereby endangering Pakistan security. Stockholm International Peace Research Institute (SIPRI) reports between 2010 and 2015 show that India imported more weapons than any other country in the world except KSA (Figure-4). 
The items on the Indian list for import in the coming decades presents a bleak picture for Pakistan's defence too. New Delhi is investing $\$ 100$ billion to acquire new conventional force capabilities in the next decades, and which, according to Pakistan's military analysts, includes the type of weapons that could be used against Pakistan (Maleeha Lodhi, 2014), Munir Akram, 2015), and in some cases, conceivably against both China and Pakistan.

TOP ARMS IMPORTER (2016-2020IN BILLION DOLLARS)

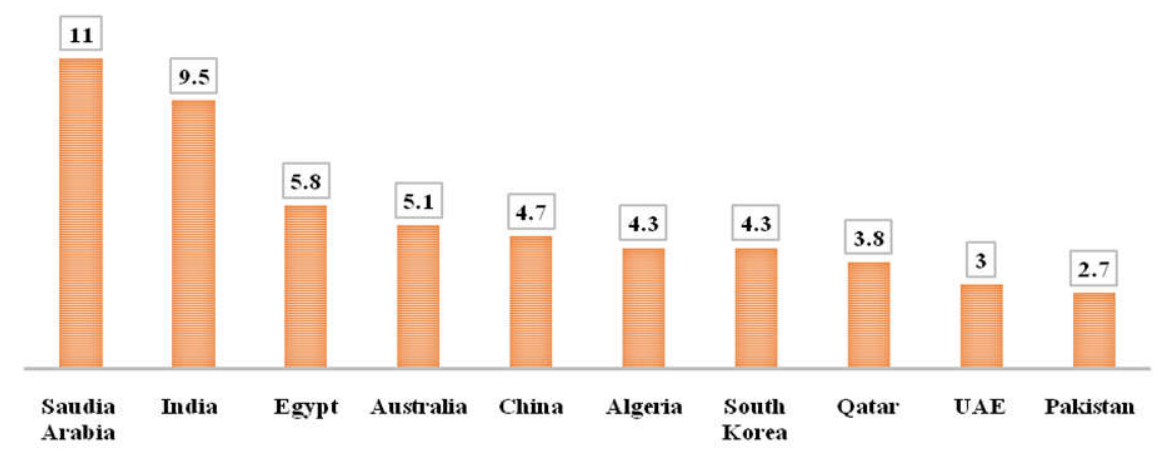

Figure-4: Top Arms importer nations between 2016-2020 www. gphandlahdpffmccakmbngmbjnjiiahp/https://sipri.org/sites/default/files/2021 -03/fs_2103_at_2020.pdf

Consequently, India's drive to strengthen its tremendous war machine is upsetting the conventional deterrents in South Asia, as this arms development is providing India with a huge conventional military advantage over Pakistan. Washington's efforts to enhance its defence ties with India to prepare it as a counterweight to an emerging China is heavily shifting balance of power in India's favour. Many critics believe that Islamabad's inability to keep pace with India is inspiring it to embrace low yield tactical nuclear weapons that can be used in the battlefield to overcome Indian conventional superiority (Feroz Hassan Khan, 2011), Malik Qassim Mustafa, 2012, Zachary Keck, 2013). Thus, Indian's military might, coupled with its drive to acquire weapons, has increased the perceived threat to Pakistan.

Most significant of all the offensive strategies is the Indian military 'cold start strategic doctrine' to defeat Pakistan. Theoretically, the doctrine is aimed to swiftly move Indian armed forces to punish Pakistan for its alleged activists inside India before the international community intervenes and pushes for a ceasefire. The central of 
premise of the doctrine is the agility and swift movement of Indian land forces, to not only carry out attacks but to penetrate deeply inside Pakistani territory with the air force providing fire power and air cover. Conventionally, Indian armed forces, stationed in central India, take almost a month to mobilize, but the doctrine is intended to reduce this time to less than 48 hours. The doctrine, which is believed based on the German General Gudarian's concept of 'Blitzkrieg' and which has been denied by Indian leadership, is considered by Pakistan to seriously undermine its security (Khalid Masood Khan, 2015). In a nutshell, India, with a huge offensive capability, is a source of serious threat to the political independence of Pakistan, which forces Pakistan to seek some balancing strategies.

\section{AGGRESSIVE INTENSIONS}

Walt maintains that it is intentions, not power, which matters (Walt, 1987:26). We can see that India is powerful, but it is the Indian intent to undo Pakistan which is more significant, and the primary concern of Pakistani policy makers has long been that India is not reconciled to the very idea of Pakistan (Sattar Khan, Personal Communication, December 12, 2015). It was the perception of Indian Muslims that they would have a better life in post-colonial India, if freed from Indian dominance; they were afraid that living with Hindus in a united India would deprive them of their socio-economic, political, and religious set up. However, this independence did not improve Indian Muslims sense of security as India would not accept the birth of Pakistan. To the Indian elite, the establishment of Pakistan represents a tragedy, the dissection of the body of 'mother' India. After the partition, statements made by Indian leaders cast doubts over the viability of the state of Pakistan, with some extreme views expressed about restoring 'Akhand Bharat' (greater India) by undoing the partition (Christophe Jaffrelot, 2016).

Commenting on the partition, Nehru said, "It may be that in this way, we shall reach that united India sooner than otherwise" (Stanley Walport, 2006:153). The All India Congress Committee announced that "The picture of India we have learnt to cherish will remain in our minds and our hearts" (Abdul Sattar Khan, 2005:15). Another prominent Indian leader, Sardar Patel once remarked " $[\mathrm{t}]$ hat the new state of Pakistan was not viable and could not last, and that the acceptance of Pakistan would teach the Muslim League a lesson, 
Pakistan would collapse in a short time" (Abdul Sattar Khan, 2005:15). While on another occasion, Patel claimed that "sooner than later we shall again be united in common allegiance to our country" (Tan Tai Yong Gyanesh Kudaisya, 2000:75). Both Nehru and Krishna Menon conceded that Congress had accepted partition to get rid of the British (Ziring, 1973:9). Achraya Kriplani, the then president of the Congress, expressed, with great anti-Muslim bias, "[n]either congress nor the nation has given up its claim of a united India" (Khan, 1967:115). Likewise, Nehru and Patel claimed yet again stated that "Pakistan would prove insolvent after it was born and, in the not-toodistant future, Jinnah and Liaquat would beg forgiveness and ask for permission to re-join India's union" (Stanley Walport, 2006:153).

Finally, Islamabad's interaction with Kabul is not pleasant entirely. Although, the notion of geography is relevant in case of Afghanistan, it is a relatively weak state when compared with Pakistan. Afghanistan's military posturing and aggregate power have rarely threatened Pakistan, it is the external support mainly from the corridors of New Delhi and, to a certain extent Moscow (particularly during the Soviet invasion of Afghanistan), that has threaded Pakistan's security. Moreover, it is the post 9/11 Indian influence in Afghanistan, and which have a profound effect on Pakistan's national security. Furthermore, the border dispute between the two states has continually troubled the decision-makers in Pakistan.

\section{CONCLUSION}

Implication of Walt's Theory for Pakistan's Alliance Making With China: This study has tried to discern/appraise Pakistan's security challenges and the need for the alliance using Walt's BoT theory framework. We have observed that the security threats are severe, and mainly emanate from Islamabad's regional environment, which is charged with ill will and tension. Pakistan was born one of the most insecure states in the world, and it has lived in a constant fear of India dominance. Therefore, the main objective of Islamabad's foreign policy is to seek national security through external alliances. While the idea of an alliance is relatively basic, alliances are of prime importance to the national security of Pakistan.

Using Walt's BoT theory, we can clearly see that the factor which creates the need for an alliance is the security threat from India. To elaborate, the Indian aggregate power, geographical proximity, 
aggressive intentions, and offensive capability pose a real threat to Pakistan's security. In the face of a growing asymmetry, Pakistan seeks extraterritorial help to balance the Indian threat. Any slight modification in Walt's four factors will essentially change Pakistan's threat perception, for instance, if the Indian leaders were not harbouring aggressive intentions against Pakistan and they had not issued statements about the integration of Pakistan into Akhand Bharat, then Islamabad would have been unlikely to have pursued balancing strategies against it. If India had not forcibly annexed the princely states of Jammu and Kashmir, which wanted to affiliate with Pakistan at the time of partition, Pakistan would have not had felt the threat to its survival from India, and if India had not played a central role in dismembering Pakistan in 1971, Pakistan would not have felt the need for an alliance.

Furthermore, if India had not gone on its weapons purchasing spree and did not mobilize its troops on the Pakistani border on numerous occasions, and more importantly, had not developed military doctrine to target Pakistan, Pakistan would have less need (though not necessarily no need) for an alliance to balance the Indian threat. Last but not the least, had India not considered South Asia its spheres of influence, Pakistan would have been unlikely to invite extra-territorial powers into South Asia to counter-balance India.

To answer the question, why does Pakistan need an alliance, it has been shown that it has been required to correct the imbalance of threat in South Asia and to address Pakistan's unremitting distress since independence. Pakistan response, however, has not solely been external balancing. Pakistan possesses nuclear weapons. Pakistan cultivates both internal and external balancing: internally it seeks nuclear weapons, and externally it cultivates alliances. Nevertheless, it is evident that the issues that drive Pakistan's need for the alliance are not only India's preponderant power in South Asia, but also its geography, offensive power, and aggressive intentions.

\section{PAKISTAN-CHINA ALLIANCE}

India has been an important factor in the Sino-Pakistan alliance. Although the strength of India as an adversary has varied over time, Indian factor has been constant. While during the Cold War, India appeared to be a strong factor in affecting Sino-Pakistan, after the war, 
though the changing dynamism like Indo-US strategic partnership may push India again as a common factor to be balanced.

Historically, Pakistan-China relations were mainly strained during the 1950s due to Pakistan's pro-west leaning. During this period, Pakistan's security needs, leadership orientation, and internal turmoil had made security elites less enthusiastic towards a communist China, and generally, until about 1960 Pakistan had a discreet relationship with China. The international developments in the early part of the 1960s brought into clear focus the commonality of the state interests of China and Pakistan, pre-empting potential tension and conflict between them such as that had occurred between China and India in 1959 as a result of their border dispute (Hassan Askari Rizvi, Personal Communication, November 12, 2015).

Warned by this Sino-Indian rivalry, and Pakistan's disappointing experience with the west, President Ayub Khan took the initiative in 1960s and proposed to China the delimitation and demarcation of the border between China's province of Xinjiang and the northern areas of Pakistan Kashmir. China, which had already developed differences with India over the Tibet issue, and later fought a brief war with India in 1962, made a positive response to Khan's overtures. China had also been feeling isolated with both Superpowers opposed to it with the advent of Sino-Soviet rift in 1959. India manipulated Chinese isolation by approaching both major powers. Thus, India had proximity, an offensive power, and had expressed aggressive intentions towards both China and Pakistan, and so an alliance between Pakistan and China was required to counter-balance India.

To China's advantage, Pakistan adopted the "One China Policy" and refused to recognize Taiwan as the lawful government of China. This common threat had necessitated an alliance to balance India; China's support to Pakistan against India was greatly appreciated by the policy makers in Pakistan India (Shamshad Ahmad Khan Personal Communication, June 20, 2015). Pakistan championed Beijing's entry into the United Nations, as well as acting as a mediator in the Sino-US rapprochement of 1970 India (Riffat Hussain, Personal Communication, July 20, 2015). Until the end of 1980s, Pakistan and China maintained extraordinarily strong relations, in the words of Ahmed Faruqi, "smooth as silk" (Faruqi, 2003:79). 
Nonetheless, strategic transformation and structural changes in the post-Cold War international relations made Pakistan-China relations fragile. The sudden and unexpected rise of the Taliban, their support to the Uighurs separatists in Xinjiang and several terrorist attacks on Chinese nationals in Pakistan have interrupted the delicate Pakistan-China equation. Despite what appeared to be good relations, their overall security ties remained, at best, tepid. Indeed, bilateral relations between Pakistan and China reached an unprecedented nadir in May 1999, in the wake of the outbreak of a small-scale war on the hills of Kargil between Pakistan and India. The Kargil war unexpectedly elicited China's neutrality towards Pakistan-India disputes. Moreover, China had adopted strict neutrality on the Kashmir issue. Although both governments endeavoured to give the impression that their fragile relationship was still strong, tested by adversity, as the Pakistani and Chinese like to say, but it was far from the reality. Transitory irritants in bilateral relations have resulted in Chinese pressure on Pakistan to safeguard its citizens against threat of terrorism apart from not siding with the Uighur Muslims.

In recent years, the Pakistan-China alliance has evolved from a security-focused partnership to a comprehensive partnership. Traditionally, Pakistan-China cooperation has been found to counterbalance India, particularly in the security and defence sectors, but there has been no economic content. In 2002, both countries agreed to develop the Gwadar deep seaport, but it was not until 2013 that Pakistani and Chinese leaders signed the CPEC's flagship project. China has promised to invest more than $\$ 60$ billion in Pakistan's communication, energy, and information technology sectors. Despite security and threat challenges from major power and regional power hostile spy agencies, the first phase of CPEC has been completed and the second phase has begun. Terrorist attacks have occurred targeting Chinese nationals in Pakistan, but this has not deterred two countries from moving forward.

\section{REFERENCES}

Abdul Sattar Khan. (2007). Pakistan's Foreign Policy 1947- 2005: A Concise History. Oxford University Press.

Adnan, M., \& Fatimais, B. (2020). China-Pakistan economic corridor: a road to development and its challenges. South Asian Studies, 31(2).

Ahmad Rashid. (2002). Taliban: Militant Islam, Oil and Fundamentalism in Central Asia. I.B. Taurus. 
Ali, L., Mi, J., Shah, M., Shah, S. J., \& BiBi, K. (2017). The potential socioeconomic impact of china Pakistan economic corridor. Asian Development Policy Review, 5(4), 191-198.

Ali, G. (2017). China-Pakistan Relations: A historical analysis. Karachi: Oxford University Press.

Beckley, B. M. (2012). China and Pakistan : Fair-Weather Friends. Yale Journal of International Affairs, 9-22.

Boni, F. (2019). Sino-Pakistani Relations: Politics, military and regional dynamics. Routledge.

Chai, W. (2015). Andrew Small The China-Pakistan Axis: Asia's New Geopolitics New York, NY: Oxford University Press 288 pp., $\$ 50.00$ cloth ISBN: 9780190210755 Publication Date: February 2015 . Asian Affairs: An American Review, 42(3):169-170. https://doi.org/10.1080 /00927678. 2015.1061832

Chaudhri, M. A. (1986). Strategic and military dimensions in Pakistan-China relations. Pakistan Horizon, 39(4):15-28.

Cheema, P. I. (2013). Security Threats Confronting Pakistan. NIDS Joint Research Sr. 9, November 1983:127-141. http://www.nids.go.jp/english/ publication/joint research/series $9 / \mathrm{pdf} / 10 . \mathrm{pdf}$

Curtis, L., Scissors, D., \& Ph,D. (2012). The Limits of the Pakistan-China Alliance. Backgrounder, The Heritage Foundation, 2641, 1-12.

Farooq Hasnat. (2011). Global Security Watch. PRAEGER.

Faruqi, A. (2003). Rethinking the National Security of Pakistan: The Price of Strategic Myopia. Ashgate.

Gulick Edward. (1967). Europe's Classical Balance of Power. New York, Norton.

Garver_China's Anti-encirclement Struggle.pdf. (n.d.).

Harsh V. Pant. (2012). The Pakistan Thorn in China - India - U.S. The Washington Quarterly, 35(1):83-95.

Hans Morgenthau. (1948). Politics Among Nations. Knopf, New York.

Hasan Askari Rizvi. (1993). Pakistan and the Geostrategic Environment. St.Martin's Press.

Hussain, I., Hussain, I., \& Qambari, I. H. (2020). History of Pakistan-China Relations: The Complex Interdependence Theory. The Chinese Historical Review, 27(2):146-164.

Jayshree Bajoria. (2009). The Troubled Afghan-Pakistani Border. https://www.cfr.org/backgrounder/troubled-afghan-pakistani-border

Javaid, U., \& Javaid, R. (2016). Strengthening geo-strategic bond of Pakistan and China through geo-economic configuration. Pakistan Economic and Social Review, 54(1):123-142.

Javaid, U., \& Jahangir, A. (2015). Pakistan-China strategic relationship: A glorious journey of 55 years. Journal of the Research Society of Pakistan, 52(1).

Kayani, F., Ahmed, M., Shah, T., \& Kayani, U. (2013). China-Pakistan Economic Relations: Lessons for Pakistan. Pakistan Journal of Commerce and Social Sciences, 7(3):454-462. 
Kenneth N. Waltz. (1979). Theory of International Politics. McGraw-Hill.

Khan, M. A. (1967). Friends not Master, A Political Autobiography. Oxford University Press.

Khan, M. M., \& Kasi, M. (2017). Pakistan-China Relations. Strategic Studies, 37(3):55-74.

Kumar, A. (2006). China-Pakistan economic relations. Institute of Peace and Conflict Studies (IPCS).

Lai, H., \& Lu, Y. (Eds.). (2012). China's soft power and international relations (Vol. 23). Routledge.

Marvin G. Weinbaum. (1994). Pakistan and Afghanistan Resistance and Reconstruction. West View.

Marvin G. Weinbaum. (1991). Pakistan and Afghanistan: The Strategic Relationship. Asian Survey, 31(June).

Munir, M. (2018). Pakistan-China Strategic Interdependence. Strategic Studies, 38(2):21-42.

Muhammad, S., Daud, S., \& Aziz, F. (2020). China-Pakistan Economic Relations: A Review Of First Two Decades Of 21st Century. Pakistan Journal of International Affairs, 3(2).

Nilofar, M., Jiang, W. S., \& Ishtiaque, M. (2014). The growing economic ties between Pakistan and china and its impact on the economy of Pakistan. IMPACT: International Journal of Research in Humanities, Arts and Literature, 2(12):49-54.

Rais, R. B. (1993). Afghanistan and the Regional Powers. Asian Survey, 33(9).

Rizvi, H.-A. (2002). Pakistan's Strategic Culture. South Asia in 2020: Future Strategic Balances and Alliances (M. R. Chambers (Ed.)).

Shahid M.Amin. (2000). Pakistan Foreign Policy: A Reappraisal. Oxford University Press.

Shanglin, L. (2001). Pakistan-China Relations. Pakistan Horizon, 54(3):13-15.

Siddique, B. R. R. and A. (2006). Resolving the Pakistan-Afghanistan Stalemate. In US Institute of Peace.

Small, A. (2015). The China-Pakistan Axis: Asia's New Geopolitics. Oxford University Press.

Stanley Walport. (2006). Shameful Flight, The Last Year of British Empire in India. Oxford University Press.

Stephen P. Cohen. (2013). Shooting for a Century: The India-Pakistan Conundrum. Brookings Institution Press.

Walt, S. M. (1985). Alliance Formation and the Balance of World Power. International Security, 9(4), 3. https://doi.org/10.2307/2538540

Walt, S. M. (1987). The Origins of Alliances. Cornell University Press.

Weidong, S. (2017). Pakistan-China relations: CPEC and beyond. Policy Perspectives: The Journal of the Institute of Policy Studies, 14(2):3-12.

Ziring, S. M. B. and L. (1973). Pakistan Foreign Policy: An Historical Analysis. Oxford University Publisher. 